\title{
Pengembangan Bicara Anak melalui Media Visual
}

\author{
Nurul Khasana Kaya \\ Jurusan Pendidikan Guru Pendidikan Anak Usia dini, Fakultas Ilmu Pendidikan \\ Universitas Negeri Gorontalo \\ Kayanurul27@gmail.com
}

\begin{tabular}{l} 
Info Artikel \\
\hline Sejarah Artikel: \\
Diterima (Juli) (2020) \\
Disetujui (Juli) (2020) \\
Dipublikasikan (Juli) (2020)
\end{tabular}

Keywords:

Development of speech; Early Childhood; Visual Learning Media

\begin{abstract}
Abstrak
Permasalahan dalam penelitian ini adalah dalam proses pembelajaran terdapat siswa ketika diberi pertanyaan oleh guru, namun tidak mau menjawab selain itu, kosa kata yang dimiliki anak masih sedikit. Tujuan penelitian ini adalah untuk mengetahui pengembangan bicara anak usia dini melalui media yang diberikan di TK. Penelitian ini merupakan penelitian deskriptif kualitatif, dengan seting penelitian yang dilaksanakan di TK. Adapun subjek penelitiannya adalah guru pada kelas yang akan dipilih. Sedangkan informasi penelitiannya adalah kepala sekolah. Pengumpulan data dilakukan dengan teknik observasi, wawancara, dan dokumentasi. Untuk menguji kesalahan data dilakukan dengan teknik triangulasi sumber dan metode. Analisis data menggunakan metode analisis interaktif dengan cara pengumpulan data, reduksi data, penyajian data, dan penarikan kesimpulan. Hasil penelitian pengembangan bicara anak usia dini di TK ini dioptimalkan dengan langkah penggunaan media pembelajaran, yaitu perencanaan dilakukan pada saat sebelum kegiatan belajar, menyiapkan rencana kegiatan harian dan media yang akan digunakan, selanjutnya guru memberikan penjelasan kepada murid tentang kegiatan pembelajaran yang akan dilaksanakan.
\end{abstract}

\begin{abstract}
The problem in this study is that in the learning process there are students when given questions by the teacher, but do not want to answer other than that, the vocabulary that children have is still small. The purpose of this study was to determine the development of early childhood speech through media provided in kindergarten. This research is a qualitative descriptive study, with the setting of research conducted in kindergarten. The research subject is the teacher in the class to be selected. While the research information is the principal. Data collection is done by observation, interview, and documentation techniques. To test data errors, the source triangulation techniques and methods are used. Data analysis uses interactive analysis methods by collecting data, reducing data, presenting data, and drawing conclusions. The results of research on early childhood speech development in kindergarten are optimized with the steps of using instructional media, namely planning is done before learning activities, preparing daily activities plans and media to be used, then the teacher gives an explanation to students about the learning activities to be carried out
\end{abstract}




\section{Pendahuluan}

Pendidikan anak usia dini memegang peranan penting dan menentukan bagi perkembangan anak selanjutnya. Karena pendidikan anak usia dini merupakan fondasi dasar bagi kepribadian anak sehingga anak mendapatkan pembinaan sejak dini. Salah satunya adalah dalam mengembangkan kemampuan berbicara, karena berbicara berperan penting dalam kehidupan. Seperti yang tertera dalam Undang-Undang Nomor 20 Tahun 2003 tentang Sistem Pendidikan Nasional disebutkan bahwa pendidikan adalah usaha sadar dan terencana untuk mewujudkan suasana belajar dan proses pembelajaran agar peserta didik secara aktif dapat mengembangkan potensinya dirinya untuk memiliki kekuatan spiritual keagaamn, pengendalian diri, kepribadian, kecerdasan, akhlak mulia serta keterampilan yang diperlukan dirinya, masyarakat, bangsa dan negara.

Dengan berbicara, seseorang dapat mengenal dan memahami dirinya, sesama dan juga lingkungan hidupnya. Selain itu, dengan berbicara dapat mengutarakan ideide, gagasan pemikiran, hal-hal yang baru maupun yang ingin diketahui melalui bicara. Seperti yang telah dikemukakan oleh Vygotsky menurut Astuti dalam Mulyasa, mengemukakan bahwa bicara merupakan sumber penting dalam pendidikan anak usia dini. Di samping itu, Vygotsky juga mengemukakan bahwa pengalaman interaksi sosial merupakan hal yang penting bagi perkembangan proses berpikir anak, sehingga aktivitas mental yang tinggi pada anak dapat terbentuk melalui interaksi dengan orang lain dan lingkungannya (Mulyasa, 2012). Kecerdasan verbal penting bukan hanya untuk keterampilan berkomunikasi melainkan juga penting untuk mengungkapkan pikiran, keinginan dan pendapat seseorang (Christine, 2008).

Awal masa kanak-kanak umumnya merupakan saat berkembang pesatnya penguasaan tugas pokok dalam belajar bicara, yaitu menambah kosa kata, menguasai pengucapan kata-kata dan menggabungkan kata-kata menjadi kalimat. Bicara itu sendiri merupakan bentuk bahasa yang menggunakan artikulasi atau kata-kata yang digunakan untuk menyampaikan maksud (Hurlock, 1997).

Oleh karena itu, dalam mengajak anak berbicara dengan menggunakan bahasa yang mudah dimengerti oleh anak. Hingga anak dapat bercakap-cakap dengan teman, 
guru dan juga orang lain. Di dalam bicara, anak masih tetap memerlukan bimbingan dari guru ataupun orang tua di rumah (Danar, 2009).

Dengan komunikasi, dapat membantu anak untuk mengembangkan kepercayaan dirinya dan hubungan-hubungan yang baik dengan orang lain. Menurut Palkhivala, komponen penting dalam mengajar bicara anak, yaitu mengajarkan anak untuk menggunakan kata-kata yang benar (Christiana, 2012). Maka dari itu perlu adanya upaya untuk mengembangkan kemampuan bicara pada anak, karena pada dasarnya anak mudah sekali untuk meniru, jadi sebagai seorang guru harus mampu membangkitkan kemauan siswa untuk mempelajari tentang suatu hal, dan bagi guru juga perlu dalam menggunakan media pembelajaran semenarik mungkin agar dalam kegiatan belajar tidak monoton dan dalam proses pembelajaran murid dapat antusias dalam mengikuti proses pembelajaran. Bicara merupakan peranan penting dalam kehidupan anak. Bicara dapat memberikan pengaruh yang besar bagi penyesuaian sosial dan pribadi anak. Oleh karena itu, diperlukan perhatian terhadap cara anak dalam belajar berbicara (Trianto, 2013). Guru juga harus dapat menciptakan suasana pembelajaran yang menyenangkan dan bervariasi sehingga menjadikan kegiatan pembelajaran lebih menarik perhatian siswa, itu merupakan suatu tantangan bagi guru, seorang guru harus berusaha untuk mengetahui cara yang tepat untuk menciptakan situasi pembelajaran yang tidak monoton. Sebagai seorang pendidik dalam menyikapi hal tersebut, haruslah dapat bertindak secara bijaksana dalam mengambil keputusan dan juga tindakan. Dan yang tidak kalah penting, guru harus berusaha semaksimal mungkin tentang bagaimana membentuk kepribadian siswa agar menjadi baik sesuai dengan tujuan pendidikan, sehingga dapat terbentuknya kepribadian anak yang baik sesuai dengan tujuan yang telah diharapkan. Oleh karena itu, pengaruh guru terhadap para siswanya sangat besar dan sangat menentukan (Suyanto, 2013).

\section{Metode Penelitian}

Metode Penelitian merupakan cara ilmiah untuk mendapatkan data dengan tujuan dan kegunaan tertentu (Sugiyono, 2011). Metode penelitian ini adalah metode kualitatif deskriptif. Penelitian kualitatif adalah tradisi tertentu dalam ilmu pengetahuan sosial yang secara fundamental bergabung dari pengamatan pada manusia dalam kawasannya maupun dalam peristilahannya. Dengan kata lain metode kualitatif 
sebagai prosedur peneletian yang menghasilkan data deskriptif berupa kata-kata dan tulisan atau lisan dari orang-orang dan perilaku yang diamati (Moleong, 2002).

Dari pendapat di atas metode ini digunakan untuk mendeskripsikan atau menjelaskan dan membahas gambaran secara lebih jelas mengenai tentang pengembangan bicara anak usia dini di Bustanul Athfal Gatak Delanggu.

Jenis Penelitian

Jenis penelitian yang dilakukan yaitu dengan cara penelitian deskriptif kualitatif yaitu penelitian yang cenderung menggunakan analisis. Proses dan makna (perspektif subjek) lebih ditonjolkan dalam penelitian kualitatif. Landasan teori dimanfaatkan sebagai pemandu agar fokus penelitian sesuai dengan fakta dilapangan.

Prosedur

Menurut Sugiyono (2007), terdapat tiga tahap utama dalam penelitian kualitatif, yaitu: 1) Tahap deskripsi atau tahap orientasi yaitu pada tahap ini, peneliti mendeskripsikan apa yang dilihat, didengar dan dirasakan. Peneliti baru mendata sepintas tentang informasi yang diperolehnya. 2) Tahap reduksi yaitu peneliti mereduksi segala informasi yang diperoleh pada tahap pertama untuk memfokuskan pada masalah tertentu. 3) Tahap seleksi yaitu peneliti menguraikan fokus yang telah ditetapkan menjadi lebih rinci kemudian melakukan analisis secara mendalam tentang fokus masalah. Hasilnya adalah tema yang dikonstruksi berdasarkan data yang diperoleh menjadi suatu pengetahuan, hipotesis, bahkan teori baru.

Data, Intrumen, dan Teknik Pengumpulan Data

Menurut Afifuddin (2012), analisis data merupakan proses mengatur urutan data mengorganisasikannya ke dalam suatu pola, kategori dan satuan uraian dasar.

Adapun analisis data yang digunakan dalam penelitian ini adalah analisis deskriptif kualitatif. Adapun teknik analisis data penelitian sebagai berikut: 1) Pengumpulan Data Dalam pengumpulan data selain menggunakan data dengan observasi, wawancara dan dokumentasi juga menggunakan catatan lapangan. Menurut Bagdan dan Bilken, catatan lapangan adalah catatan tertulis tentang apa yang didengar, dilihat dan difikirkan dalam rangka pengumpulan data-data terhadap data dalam 
penelitian kualitatif (Moleong, 2002). 2) Reduksi Data Proses pembukuan atau penyederhanaan dan abstraksi data yang ada dalam "field note" yang sedemikian hingga kesimpulan dapat dilakukan.3) Penarikan kesimpulan, penarikan kesimpulam merupakan proses akhir dari penelitian. Setelah analisis data dilakukan, maka peneliti dapat menyimpulkan hasil penelitian yang menjawab rumusan masalah yang ditetapkan oleh peneliti sebelumnya. Sesuai dengan rumusan masalah, maka untuk mendapatkan data dan informan yang memadai, peneliti menggunakan berbagai teknik. Adapun teknik pengumpulan data menggunakan metode wawancara, observasi dan dokumentasi, dengan keterangan sebagai berikut:

\section{Hasil Penelitian}

Pada hasil penelitian ini saya merangkum dari apa yang saya lakukan disekolah melalui wawancara dengan guru kelas, kepala sekolah dan peserta didik dikelas tersebut.

Menurut Kamus Besar Bahasa Indonesia, bahwa pengembangan adalah perbuatan atau hal, cara usaha (poerwadarminta, 2003). pengembangan adalah proses dan cara (dendy sugono, 2008). sedangkan menurut soetopo dan soemanto mengemukakan bahwa pengembangan adalah suatu hal yang dilakukan untuk menunjukkan pada suatu kegiatan menghasilkan suatu alat atau hasil (sukirman, 2015). bicara itu sendiri merupakan bentuk bahasa yang menggunakan artikulasi atau katakata yang digunakan untuk menyampaikan maksud (hurlock, 2012).

Harus diketahui, bahwa pada dasarnya dalam mengajak anak dalam bicara, hendaknya menggunakan kata-kata yang mudah dimengerti oleh anak, maka anak akan dapat memahami maksud dari perkataan tersebut. Selain anak dapat memahami maksud dari perkataan tersebut, anak juga dapat meniru tentang bagaimana mengucapkan tentang suatu hal.

Media merupakan peranan penting dalam suatu proses pembelajaran, karena dengan menggunakan media, selain mempermudah untuk memberikan penjelasan, dengan media dapat membuat suatu proses pembelajaran menjadi lebih menarik. sehingga dengan menggunakannya suatu media pembelajaran secara benar, dapat digunakan sebagai upaya untuk mengembangkan suatu kemampuan dalam kegiatan proses pembelajaran, guru diharapkan dapat membuat kegiatan belajar secara 
menyenangkan, agar anak dapat mengikuti proses pembelajaran sesuai yang diinginkan. Kata media berasal dari bahasa latin medius, dan merupakan bentuk jamak dari kata medium yang secara harfiah berarti perantara atau pengantar. Dalam bahasa arab, media adalah perantara atau pembawa pesan dari pengirim kepada penerima pesan. Menurut Gerlach, media adalah bila dipahami secara garis besar adalah manusia, materi atau kejadian yang membangun kondisi yang membuat siswa mampu memperoleh pengetahuan keterampilan atau sikap. Dalam pengertian ini, guru, buku teks dan lingkungan sekolah merupakan media. Secara lebih khusus, pengertian media dalam proses pembelajaran cenderung diartikan sebagai alat-alat grafis, fotografis atau elektronis untuk menangkap, memproses dan menyusun kembali informasi visual atau verbal (Mukhtar, 2013). jenis media visual dalam kegiatan pembelajaran, diantaranya: 1) media visual/media grafis, media visual/media grafis adalah media yang hanya dapat dilihat. jenis media visual ini tampaknya yang paling sering digunakan oleh guru pada lembaga pendidikan anak usia dini untuk membantu menyampaikan isi dari tema pendidikan yang sedang dipelajari (mukhta, 2013). media visual terdiri dari media yang dapat diproyeksikan (projected visual) dan media yang tidak dapat diproyeksikan (nonprojected visual), dengan keterangan sebagai berikut: a) Media Visual yang tidak diproyeksikan paling banyak digunakan guru dalam pembelajaran karena paling praktis. Media ini mudah didapat, mudah dibuat, dan mudah dimanfaatkan. Pada Paud Siti Hajar ini menggunakan media pembelajaran visual untuk mengembangkan bicara pada anak, dengan menggunakannya media gambar. Dengan keterangan sebagai berikut :b) Media Gambar, Media Gambar merupakan salah satu media pembelajaran yang amat dikenal di dalam setiap kegiatan pembelajaran. Hal ini disebabkan kesederhanaannya tanpa memerlukan perlengkapan dan tidak perlu diproyeksikan untuk mengamatinya. Gambar adalah tiruan barang (orang, binatang) yang dibuat dengan coretan pensil dan sebagainya pada kertas atau lainnya.

\section{Simpulan}

Langkah persiapan, dilakukan pada saat sebelum kegiatan belajar, menyiapkan rencana kegiatan harian dan media yang akan digunakan selanjutnya guru memberikan penjelasan kepada murid tentang kegiatan pembelajaran yang akan dilaksanakan. Langkah pelaksanaan, dilakukan dalam kelompok dan individu, pelaksanaan yang 
dilakukan secara kelompok apabila waktu pembelajaran terbatas, maka pembelajaran dilakukan secara kelompok, namun murid diberikan pertanyaan satu persatu dengan bergilir. Sedangkan pelaksanaan yang dilakukan secara individu, dilakukan dengan menyuruh siswa untuk maju ke depan kelas untuk melakukan kegiatan belajar. Langkah penilaian, digunakan untuk mengetahui kemampuan yang dimiliki anak dengan cara melakukan kegiatan belajar secara mandiri, pada pembelajaran dengan metode pengembangan yang digunakan dalam proses pembelajaran dengan menggunakan metode bercerita, dan metode berdialog. Dalam proses pembelajaran, penilaian diberikan kepada siswa, apabila siswa mampu menjawab pertanyaan dari gurudan mampu mengutarakan atau menjelaskan isi dari media pembelajaran visual.

\section{Simpulan}

Berdasarkan hasil penelitian Terhadap kegiatan bermain plastisin pada TK Kartini Mopusi yang berjumblah 20 orang anak Untuk meningkatkan kreativitas anak. Peneliti melihat dari hasil bermain plastisin Anak yang belum berkembang sebanyak 8 orang. Mereka hanya bisa membentuk 1 buah saja. Anak yang mulai berkembang sebanyak 5 orang. Mereka bisa Membuat sebanyak 2 buah. Anak yang berkembang sesuai harapan sebanyak 7 orang. Mereka bisa membuat sebanyak 3 buah.

Peneliti Juga melihat bahwa hasil respon anak terhadap kegiatan bermain plastisin.Anak yang aktif sebanyak 11 orang anak dan anak yang kurang aktif 9 orang anak.

\section{Daftar Pustaka}

Aisyah, Edelweis Asti, Sukirman. (2015). "Hubungan Pengalaman, Time Budget Pressure, Kompensasi Terhadap Kualitas Audit Pada Kantor Akuntan Publik (KAP) di Kota Semarang". Accounting Analysis Journal. ISSN 2252- 6765.

Dendy, Sugono, (2008). Kamus Besar Bahasa Indonesia Edisi Keempat . Jakarta :Gramedia

Hurlock, E. B. (2012). Psikologi Perkembangan, Suatu Pendekatan Sepanjang Rentang Kehidupan (terjemahan). Jakarta: Erlangga

Moleong, Lexy. (2002). Metodologi Penelitian Kualitatif. Bandung: PT. remaja Rosdakarya. 
Mukhtar. (2013). Metode Penelitian Deskriftif Kualitatif. Jakarta : GP Press Group

Nur Adiyanti Wahyuni. (2017). Pengembangan bicara anak usia dini dengan menggunakan media pembelajaran visual di ba aisyiyah. Skripsi. Tidak diterbitkan. Fakultas Ilmu Tarbiyah dan Keguruan. Institut Agama Islam Negeri Surakarta

Reza Syehma Bachtiar. Penggunaan Media Visual Untuk Meningkatkan Hasil Belajar. Tesis. Tidak diterbitkan. PGSD FIP Universitas Negeri Surabaya

Sugiyono. (2007). Metode Penelitian Kuantitatif Kualitatif dan R\&D. Bandung: Alfabeta

Wiyani, Novan Ardy. (2016). Konsep Dasar PAUD. Yogyakarta: Javamedia 